\title{
Pengaruh Penyuluhan terhadap Peningkatan Pengetahuan Keluarga dalam Perawatan Anak Retardasi Mental
}

\author{
Afifa Ika Kridawati ${ }^{1}$ \\ ${ }^{1}$ STIKes Surya Mitra Husada Kediri \\ Email : afifa.ika39@gmail.com
}

Received 21 April 2018; Accepted 8 May 2018; Published 15 May 2018

\begin{abstract}
ABSTRAK
Tanggapan negatif masyarakat tentang anak retardasi mental menimbulkan berbagai macam reaksi orang tua yang memiliki anak retardasi mental, seperti: orang tua mengucilkan anak atau tidak mengakui sebagai anak yang retardasi mental. Anak yang retardasi mental disembunyikan dari masyarakat karena orang tua merasa malu mempunyai anak keterbelakangan mental. Kemiskinan dan letak wilayah yang terpencil menjadikan minimnya pengetahuan yang dimiliki oleh keluarga penderita retardasi mental tentang perawatan penderita. Berdasarkan hasil studi pendahuluan kejadian retardasi mental di Kabupaten Ponorogo penderitanya keseluruhan mencapai seratus orang lebih, di Desa Karangpatihan sendiri keluarga yang mempunyai anak retardasi mental sebanyak $20 \mathrm{KK}$. Penelitian ini bertujuan untuk mengetahui pengaruh penyuluhan terhadap peningkatan pengetahuan keluarga dalam perawatan anak retardasi mental. Penelitian dilaksanakan di Desa Karangpatihan Kabupaten Ponorogo pada tanggal 20 Mei sampai 27 Mei 2011. Desain penelitian yang digunakan adalah pra eksperimental dengan metode one group pra-post test design. Populasi adalah semua keluarga (ibu) yang mempunyai anak retardasi mental berjumlah 20 orang dengan tehnik pengambilan sampel menggunakan total sampling. Pengumpulan data menggunakan kuesioner dan dianalisis dengan uji Wilcoxon pada taraf kesalahan 0,05. Hasil penelitian menunjukkan pengetahuan keluarga sebelum dilakukan penyuluhan sebagian besar masih kurang sebanyak 11 orang (55\%), dan setelah dilakukan penyuluhan hampir setengah pengetahuan keluarga mengalami peningkatan sebanyak 9 orang (45\%). Hasil uji statistik Wilcoxson diperoleh nilai signifikasi $\rho=0,040, \rho<0,05$, sehingga H1 diterima. Data di atas menunjukkan bahwa setelah diberikan penyuluhan pengetahuan keluarga tentang perawatan anak retardasi mental bertambah. Sehingga penyuluhan meningkatkan pengetahuan keluarga tentang perawatan anak retardasi mental.
\end{abstract}

Kata Kunci : Pengetahuan, penyuluhan, retardasi mental.

Copyright ( 2018 STIKes Surya Mitra Husada

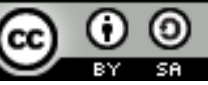

This is an open-acces article distributed under the terms of the Creative Commons Attribution-ShareAlike 4.0 International License. 


\section{PENDAHULUAN}

Fenomena dalam masyarakat masih banyak orang tua khususnya ibu yang menolak kehadiran anak yang tidak normal, karena malu mempunyai anak yang cacat, dan tak mandiri. Orang tua yang demikian akan cenderung menyangkal keberadaan anaknya dengan menyembunyikan anak tersebut agar jangan sampai diketahui oleh orang lain. Anak retardasi mental sering dianggap merepotkan dan menjadi beban bagi pihak lain. Tindakan orang tua yang demikian ini akan memperparah keadaan anak yang mengalami retardasi mental. Anak yang mengalami retardasi mental perlu perhatian dan pendidikan khusus untuk membantu perkembangan intelektual anak. Oleh sebab itu, orang tua perlu menyesuaikan dirinya dengan kehadiran anak yang berbeda dengan anak lainnya. Tanggapan negatif masyarakat tentang anak retardasi mental menimbulkan berbagai macam reaksi orang tua yang memiliki anak retardasi mental, seperti: orang tua mengucilkan anak atau tidak mengakui sebagai anak yang retardasi mental. Anak yang retardasi mental disembunyikan dari masyarakat karena orang tua merasa malu mempunyai anak keterbelakangan mental. Kemiskinan dan letak wilayah yang terpencil menjadikan minimnya pengetahuan yang dimiliki oleh keluarga penderita retardasi mental tentang perawatan penderita. Selain hal tersebut, kurangnya perhatian dari lembaga-lembaga yang berperan menangani dan mensosialisasikan perawatan penderita retardasi mental membuat jumlah penderita retardasi mental semakin hari semakin bertambah (Cahyo, 2010).

Disebutkan ada sejumlah faktor genetik yang dapat menimbulkan retardasi mental. Demikian pula halnya dengan beberapa faktor prenatal yang dialami oleh ibu-ibu yang hamil, misalnya telah sama diketahui bahwa calon ibu-ibu yang mengalami penyakit campak Jerman (Rubella) sering anak yang dikandungnya dikemudian hari akan mengalami gangguan mental retardasi. Lingkungan juga berpengaruh terhadap kejadian tersebut seperti adanya deprivasi psikososial, devripasi artinya tidak terpenuhinya kebutuhan. Tidak terpenuhinya kebutuhan psikososial awal-awal perkembangan ternyata juga dapat menyebabkan terjadinya retardasi mental pada anak (Maramis, 2009). Pada "kampung idiot", selain kemiskinan yang diduga sebagai penyebab keterbelakangan mental, juga letak wilayah yang sangat terpencil dan kurangnya perhatian dari lembaga-lembaga yang berperan menangani masalah penyandang cacat menjadi faktor pendorongnya (Cahyo, 2010).

Penanganan terhadap penderita retardasi mental bukan hanya tertuju pada penderita saja, melainkan juga pada orang tuanya. Hal ini dikarenakan siapapun orangnya pasti memiliki beban psiko-sosial yang tidak ringan jika anaknya menderita retardasi mental, apalagi jika masuk kategori yang berat dan sangat berat. Oleh karena itu agar orang tua dapat berperan secara baik dan benar maka mereka perlu memiliki kesiapan psikologis dan teknis. Untuk itulah maka mereka perlu mendapatkan konseling dan penyuluhan untuk menambah pengetahuan mereka, dengan tujuan agar orang tua penderita mampu mengatasi beban psikososial pada dirinya terlebih dahulu sehingga kemudian mampu melakukan perawatan terhadap anaknya yang menderita retardasi mental (Maramis, 2009). Pemberian informasi dimaksudkan memperbaiki dan mengembangkan pemahaman diri dan orang lain, sedangkan perubahan sikap merupakan tujuan tidak langsung (Maulana, 2009). Penderita cacat mental sebenarnya cukup dilatih di rumah oleh keluarganya agar hubungan emosional antara orang tua dan anaknya yang cacat mental harus sama dengan hubungan orang tua dengan anak anak yang normal. Saudara - saudara yang normal diberi pengertian oleh orang tuanya bahwa salah satu saudaranya ada yang cacat mental, maksudnya agar mereka tidak malu mempunyai saudara yang cacat mental. Dapat dilatih cara berpakaian, cara makan, pemeliharaan tubuh dan harus diberi kesempatan dengan anak - anak yang lain untuk bermain, tetapi harus tetap diawasi (Ichwanmuis, 2010).

Dari uraian di atas peneliti tertarik untuk melakukan penelitian mengenai pengaruh penyuluhan terhadap peningkatan pengetahuan keluarga dalam perawatan anak retardasi mental di Desa Karangpatihan Kecamatan Balong Kabupaten Ponorogo. Penelitian ini diharapkan dapat memberi terkait permasalahan yang terjadi di Desa Karangpatihan Kecamatan Balong Kabupaten Ponorogo. 


\section{METODE PENELITIAN}

Penelitian ini dilaksanakan yang dimulai dari perencanaan (penyusunan proposal) sampai dengan penyusunan laporan akhir sejak bulan Januari 2011 sampai dengan bulan Juli 2011.

Sedangkan lokasi penelitian dilaksanakan di Desa Karangpatihan Kecamatan Balong Kabupaten Ponorogo. Alasan mengambil tempat di Desa Karangpatihan karena di desa tersebut jumlah penderita retardasi mental lebih banyak dibanding desa lain dan juga pengetahuan tentang perawatan anak retardasi mental kurang, hal ini dikarenakan kondisi keluarga yang miskin serta letak wilayah yang terpencil.

Desain penelitian yang digunakan adalah pra eksperimental dengan metode one group pra-post test design yaitu penelitian yang mengungkapkan hubungan sebab akibat dengan cara melibatkan satu kelompok subjek. Kelompok subjek diobservasi sebelum dilakukan intervensi, kemudian diobservasi lagi setelah intervensi (Nursalam, 2008).

Populasi pada penelitian ini adalah semua keluarga (ibu) anak retardasi mental yang berada di Desa Karangpatihan Kecamatan Balong Kabupaten Ponorogo yang berjumlah 20 orang. Teknik pengambilan sampel dalam penelitian ini adalah total sampling.

Peneliti menggunakan instrumen berupa lembar kuesioner untuk mengidentifikasi pengetahuan keluarga dalam perawatan anak retardasi mental. Dalam penelitian ini peneliti memberikan intervensi yaitu memberikan penyuluhan tentang perawatan pada anak retardasi mental sehingga diperlukan satuan acara penyuluhan (SAP) agar penyuluhan yang diberikan dapat terarah dan sesuai dengan tujuan.

Untuk mengetahui pengaruh dari penyuluhan terhadap tingkat pengetahuan keluarga tentang perawatan anak retardasi mental di uji dengan menggunakan uji wilcoxon, dengan tingkat kesalahan $=0,05$. Jika $\rho<0,05$ maka $\mathrm{H}_{1}$ di terima yang artinya penyuluhan meningkatkan pengetahuan keluarga dalam perawatan anak retardasi mental.

\section{HASIL DAN PEMBAHASAN}

Untuk mengetahui pengaruh penyuluhan terhadap peningkatan pengetahuan keluarga tentang perawatan anak retardasi mental maka akan disajikan seperti pada dibawah ini :

Tabel 1. Tabulasi silang pengaruh penyuluhan tentang perawatan anak retardasi mental terhadap pengetahuan keluarga dalam perawatan anak retardasi mental

\begin{tabular}{|c|c|c|c|c|c|}
\hline & & \multicolumn{3}{|c|}{$\begin{array}{c}\text { Sesudah Penyuluhan Perawatan } \\
\text { Anak Retardasi Mental }\end{array}$} & \multirow[t]{2}{*}{ Total } \\
\hline & & $\mathrm{K}$ & $\mathrm{C}$ & $\mathrm{B}$ & \\
\hline \multirow{3}{*}{$\begin{array}{c}\text { Sebelum Penyuluhan } \\
\text { Perawatan Anak Retardasi } \\
\text { Mental }\end{array}$} & Kurang & 2 & 6 & 3 & 11 \\
\hline & Cukup & 1 & 2 & 3 & 6 \\
\hline & Baik & 1 & 1 & 1 & 3 \\
\hline \multirow[t]{2}{*}{$\begin{array}{r}\text { Total } \\
\end{array}$} & & 4 & 9 & 7 & 20 \\
\hline & \multicolumn{5}{|c|}{ Uji Wilcoxon $\rho=0,040$} \\
\hline
\end{tabular}

Berdasarkan tabel diatas menunjukkan bahwa sebagian besar pengetahuan keluarga sebelum dilakukan penyuluhan adalah kurang sebanyak 11 orang (55\%) dan sesudah dilakukan penyuluhan kesehatan tentang perawatan anak retardasi mental sebagian besar pengetahuan keluarga adalah cukup sebanyak 9 orang (45\%). Hal ini menunjukkan bahwa setelah diberikan penyuluhan maka pengetahuan keluarga tentang perawatan anak retardasi mental bertambah.

Berdasarkan hasil analisa menggunakan uji wilcoxon pada tingkat kesalahan $\alpha=0,05$ didapatkan bahwa $\rho<\alpha$ atau $0,040<0,05$ yang artinya penyuluhan meningkatkan pengetahuan keluarga dalam perawatan anak retardasi mental, maka $\mathrm{H}_{1}$ diterima. 


\section{Pengetahuan keluarga sebelum dilakukan penyuluhan tentang perawatan anak retardasi mental}

Sebagian besar pengetahuan responden tentang perawatan anak retardasi mental sebelum penyuluhan adalah kurang sebanyak 11 orang (55\%) dan hanya sebagian kecil yang berpengetahuan baik yaitu sebanyak 3 orang $(15 \%)$. Hal ini dikarenakan hampir setengah dari responden belum pernah mendapatkan informasi dari sumber mana pun. Jika seseorang belum pernah atau kurang mendapatkan informasi maka pengetahuan yang dimilikipun akan kurang atau rendah. Karena dengan seringnya seseorang mendapatkan informasi maka dia akan mendapatkan hal - hal baru yang mungkin sama sekali belum dia ketahui.

Sesuai yang tertulis pada Nanda (2005) menjelaskan bahwa faktor-faktor yang terkait dengan kurang pengetahuan (deficient knowledge) terdiri dari: kurang terpapar informasi, kurang daya ingat/hapalan, salah menafsirkan informasi, keterbatasan kognitif, kurang minat untuk belajar dan tidak familiar terhadap sumber informasi.

Selain karena belum pernah mendapatkan informasi tentang perawatan anak retardasi mental, letak wilayah yang terpencil membuat masyarakat minim akan informasi dari media massa baik yang cetak maupun elektronik. Karena penyebaran media massa belum bisa menjangkau wilayah tersebut. Penduduk di wilayah tersebut masih banyak yang tidak mempunyai alat - alat elektronik seperti radio ataupun televisi. Padahal menurut Notoatmodjo (2007) menyatakan bahwa dengan majunya teknologi akan tersedia pula bermacam-macam media massa yang dapat memberikan informasi sehingga mempengaruhi pengetahuan masyarakat tentang inovasi baru. Sebagai sarana komunikasi, berbagai bentuk media massa seperti televisi, radio, surat kabar, majalah, dan lain-lain mempunyai pengaruh besar terhadap pembentukan opini dan kepercayan orang. Dalam penyampaian informasi sebagai tugas pokoknya, media massa membawa pula pesan-pesan yang berisi sugesti yang dapat mengarahkan opini seseorang. Adanya informasi baru mengenai sesuatu hal memberikan landasan kognitif baru bagi terbentuknya pengetahuan terhadap hal tersebut.

Hasil kuesioner yang diberikan pada keluarga sebanyak 14 keluarga memiliki pengetahuan yang kurang tentang perawatan anak retardasi mental. Pengetahuan keluarga yang kurang akan mempengaruhi pada proses perawatan anak retardasi mental. Kemungkinan keluarga akan akan merawat anak retardasi mental dengan tidak baik jika pengetahuan yang dimilikinya kurang.

\section{Pengetahuan keluarga sesudah dilakukan penyuluhan tentang perawatan anak retardasi mental}

Hampir setengah pengetahuan responden tentang perawatan anak retardasi mental sesudah penyuluhan adalah cukup sebanyak 9 orang (45\%). Pengetahuan keluarga hampir setengah meningkat dikarenakan keluarga telah mendapatkan informasi tentang perawatan anak retardasi mental dengan adanya penyuluhan yang telah diberikan oleh peneliti. Sehingga pengetahuan keluarga yang awalnya masih kurang, setelah dilakukan penyuluhan mengalami peningkatan karena keluarga telah memperoleh informasi yang baru retardasi mental dan cara perawatan pada anak yang mengalami retardasi mental.

Sebagaimana pernyataan dari Notoatmodjo (2007) bahwa informasi yang diperoleh baik dari pendidikan formal maupun non formal dapat memberikan pengaruh jangka pendek (immediate impact) sehingga menghasilkan perubahan atau peningkatan pengetahuan.

Pengetahuan keluarga tentang perawatan anak retardasi mental meningkat juga karena adanya faktor pendukung yaitu dukungan dari perangkat desa setempat juga penduduk lain yang berperan aktif dalam upaya menurunkan angka kejadian retardasi mental di Desa Karangpatihan seperti perangkat desa melarang bila ada warganya yang mengalami retardasi mental akan dinikahkan dengan orang yang mengalami retardasi mental juga. Perangkat desa dan penduduk lainnya sering memberikan saran kepada keluarga penderita retardasi mental agar bersifat terbuka dan mau menerima bila ada kunjungan dari petugas kesehatan yang memberikan penyuluhan - penyuluhan kesehatan. Adanya motivasi dari perangkat desa dan 
penduduk lain tersebut menjadikan keluarga penderita retardasi mental mau menerima dan memahami informasi yang datang dari luar.

Teori yang dikemukakan oleh Mubarok (2007) bahwa kebudayaan dimana kita hidup dan dibesarkan mempunyai pengaruh besar terhadap pembentukan sikap kita. Apabila dalam suatu wilayah mempunyai budaya untuk menjaga kebersihan lingkungan maka sangat mungkin masyarakat sekitarnya mempunyai sikap untuk selalu menjaga kebersihan lingkungan, karena lingkungan sangat berpengaruh dalam pembentukan sikap pribadi atau sikap seseorang.

Sedangkan pengetahuan keluarga tentang perawatan anak retardasi mental masih ada yang kurang, hal ini dikarenakan oleh faktor intelegensi, perhatian, motivasi, minat, sikap dan bakat dari masing-masing individu yang berbeda dan juga dipengaruhi oleh waktu post test yang selang waktunya 1 minggu, sehingga keluarga berbeda-beda dalam menyerap, memahami, dan mengingat suatu informasi.

Hal ini sesuai dengan teori Suprapto (2009), bahwa faktor-faktor yang mempengaruhi proses belajar adalah intelegensi, perhatian, motivasi, minat, sikap dan bakat. Manusia adalah suatu organisme unik yang berkembang sesuai perkembangannya yang merupakan perkembangan seluruh aspek kepribadiannya. Proses pembelajaran dapat dipengaruhi oleh perkembangan individu yang tidak sama.

\section{Pengaruh Penyuluhan Tentang Perawatan Anak Retardasi Mental Terhadap Pengetahuan Keluarga Dalam Perawatan Anak Retardasi Mental}

Berdasarkan tabel 1 menunjukkan bahwa penyuluhan meningkatkan pengetahuan keluarga tentang perawatan anak retardasi mental yang ditunjukkan oleh hasil uji statistik Wilcoxon dengan nilai signifikansi $\rho=0,040<(\alpha) 0,05$.

Hal ini dikarenakan program penyuluhan telah terlaksana dengan baik sesuai dengan satuan acara penyuluhan serta adanya tanggapan positif dari keluarga yang mau menerima dan memahami informasi baru yang datang dari luar. Sehingga pengetahuan keluarga tentang retardasi mental pun bertambah, bahkan keluarga telah mampu mengaplikasikan cara perawatan anak retardasi mental sesuai dengan informasi yang diberikan saat penyuluhan. Jadi dengan lebih sering memberikan informasi kepada keluarga seperti dilakukannya penyuluhan akan membuat keluarga tahu bagaimana cara mengatasi agar angka kejadian retardasi mental di wilayah tersebut tidak terus meningkat.

Berdasarkan dari konsep penyuluhan kesehatan merupakan suatu bentuk kegiatan pendidikan kesehatan yang dilakukan dengan menyampaikan pesan,menanamkan keyakinan, sehingga masyarakat tidak saja sadar, tahu dan mengerti tetapi juga mau dan bisa melakukan anjuran yang ada hubungannya dengan kesehatan (Notoatmodjo, 2003). Untuk mendapatkan suatu pengetahuan perlu diadakan suatu program penyuluhan yang mengarah pada memberikan suatu pendidikan kepada masyarakat misalnya tentang menekankan ketrampilan hidup sehat, sehingga masyarakat tidak hanya memperoleh pengetahuan, tetapi akan memberikan arti tinggi dalam proses pengetahuan (Machfoed, 2007). Menurut Notoatrmodjo (2009) pendidikan kesehatan masyarakat dapat dilakukan dengan memberikan penyuluhan kepada masyarakat. Upaya pemberian informasi melalui penyuluhan diharapkan dapat meningkatkan pengetahuan masyarakat tentang kesehatan masyarakat sehingga mereka dapat mengambil keputusan- keputusan dan sikap atas dasar informasi yang memadai.

\section{KESIMPULAN}

Berdasarkan penelitian pengaruh penyuluhan tentang perawatan anak retardasi mental terhadap pengetahuan keluarga dalam perawatan anak retardasi mental dapat diambil kesimpulan sebagai berikut :

1) Pengetahuan keluarga dalam perawatan anak retardasi mental di Desa Karangpatihan sebelum dilakukan penyuluhan sebagian besar masih kurang.

2) Pengetahuan keluarga dalam perawatan anak retardasi mental di Desa Karangpatihan sesudah diberikan sebagian besar cukup (mengalami peningkatan). 
3) Penyuluhan meningkatkan pengetahuan keluarga dalam perawatan anak retardasi mental.

\section{DAFTAR PUSTAKA}

Cahyo. (2010). Duh.. Ada 'Kampung Idiot' Baru di Ponorogo. From : http://www.beritajatim.com (di akses januari, 2011).

Ichwanmuis. (2010). Penyandang Tuna Grahita. From : http://www.ichwanmuisblog.blogspot.com (di akses januari, 2011).

Machfoedz. (2007). Promosi Kesehatan. Jakarta : Rineka Cipta.

Maramis. (2009). Catatan Ilmu Kedokteran Jiwa Ed. 2. Surabaya : Airlangga University Press.

Maulana. (2009). Promosi Kesehatan. Jakarta : EGC.

Mubarok. (2007). Promosi Kesehatan Sebuah Pengantar Proses Belajar Mengajar Dalam Pendidikan. Yogyakarta : Graha Ilmu.

Nanda. (2005). Nursing Diagnoses : Definition and Classification 2005 - 2006. Philadelphia : Nanda Internasional.

Notoatmodjo. (2003). Ilmu Kesehatan Masyarakat : Prinsip-Prinsip Dasar. Jakarta : Rineka Cipta.

Notoatmodjo. (2007). Perilaku Kesehatan Masyarakat. Jakarta : Rineka Cipta.

Notoatmodjo. (2009). Metode Penelitian, Jakarta : Rineka Cipta.

Nursalam. (2008). Konsep dan Penerapan Metodologi Penelitian Ilmu Keperawatan, Surabaya : Salemba Medika. 